\title{
サル血小板膜糖蛋白および凝集能に関する検討
}

$\begin{array}{llll}\text { 鈴木正彦*, } & \text { 川勝俊宏*, } & \text { 永田博一*, } & \text { 岩田弘滋* } \\ \text { 柳父睦政*, } & \text { 曽我哲司*, } & \text { 曽根尚明*, } & \text { 野村昌作* } \\ \text { 粉川皓年*, } & \text { 安永幸二郎* } & & \end{array}$

\section{Monkey Platelet Membrane Glycoproteins and Aggregation}

\author{
Masahiko SUZUKI*, Toshihiro KAWAKATSU*, Hirokazu NAGATA*, Koji IWATA* \\ Mutsumasa YANABU*, Tetsuji SOGA*, Naoaki SONE*, Shosaku NOMURA* \\ Terutoshi KOKAWA* and Kojiro YASUNAGA*
}

Key words : human platelet, monkey platelet, glycoprotein, aggregation, monoclonal antibody

The monkey is classified as close to the human and is important as an experimental animal. The present study, a comparison of human and monkey platelet membrane glycopreteins and aggregation, was undertaken.

The major platelet membrane glycoprotein was similarly represented in humans and monkeys by SDS-polyacrylamide gel electrophoresis and PAS staining. Crossed immunoelectrophoresis showed that EDTA dissociated both human and monkey platelet GP IIb/IIIa complex. In monkey platelets, ADP-induced aggregation was slightly weaked than in humans. High concentrations of ristocetin were required to agglutinate monkey platelets. Human and monkey platelets were aggretated by collagen and thrombin in the same manner. Epinephrine did not induce aggregation in monkey platelets. All of five monoclonal antibodies against human platelet GP IIb/IIIa complex bound to monkey platelets, and inhibited monkey platelet aggregation induced by $\mathrm{ADP}$ and collagen. A monocolnal anti-human platelet GP Ib antibody which has no effect on either human platelet aggregation induced by thrombin or agglutination induced by ristocetin bound to monkey platelets. But an anti-GP Ib antibody which inhibits human platelet agglutination induced by ristocetin did not bind to monkey platelets. Both of two monoclonal antibodies against human CD9 antigen bound to monkey platelets and aggregated monkey platelets.

These rusults indicate that human and monkey platelets are similar in terms of antigenicity and function, especially GP IIb/IIIa complex. It is suggested that the monkey is a useful animal model for analysis of the effects of monoclonal anitbody against human platelets in vivo. 


\section{はじめに}

医学研究において実験に動物を用いる場合, ヒトにおけるさまざまな疾患や病態の解明ある いは治療法の検討が目的とされることが多い. 実験動物の選択に際しては，その動物の入手方 法や取り扱い方法が容易であるかどうかという ことも考慮されるが, 目的とする臓器や細胞あ るいはそれらをとりまく環境がヒトとどれだけ 類似しているかということも重要な要素であ る. 分類学上サルはヒトに最も近縁であり, 形 態学的にも生理学的にもあるいは生化学的にも ヒトと類似している点が多いと言われている. しかし血小板研究の分野では, ブタ1) 5)，イ ヌ6) 8)，ウサギ9) 11)などの血小板がよく用いら れており，サル血小板に関する詳細な報告はな い.そこで今回，サル血小板膜糖蛋白 (GP) および血小板凝集能に関し検討し，さらに抗七 ト血小板抗体のサル血小板に及ほす影響につい ても検討した.

\section{I. 材料および方法}

\section{1. 実験動物}

実験動物として 2.5 ないし $6.0 \mathrm{~kg}$ のニホン ザル 8 頭を用いた。

\section{2. 抗ヒト血小板抗体}

ヒト血小板抗体として，当教室で作製した 9 種のモノクローナル抗体を用いた。その内訳 は, 抗 GP IIb/IIIa 複合体抗体が 5 種類 (NNKY 1-32，2-5，2-6，2-11 および 2-

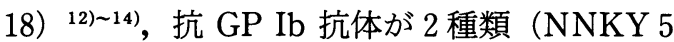
-4 および 5-5) 12)14), CD 9 抗体が 2 種類 (NNKY 1-19 および MALL 13) 15)16)である. 実験に際しては,各モノクローナル抗体を産生 するハイブリドーマより得られたマウス腹水を 硫安塩析法およびイオン交換法により精製して 用いた。また一部の抗体は，精製した IgG 分 画をペプシン消化することにより $\mathrm{F}\left(\mathrm{ab}^{\prime}\right)_{2}$ 分 画を，またパパイン消化することにより Fab 分画を作製し実験に用いた。

\section{SDS-PAGE}

チトラート加血より得た多血小板血漿 (PRP) を ethylenediamine tetraacetic acid (EDTA)-phosphate buffered saline (PBS) (一) で 2 回洗浄後, reduced sample buffer $に$ て溶解した。 引き続き, Laemmli ${ }^{17)}$ の方法に て SDS-PAGE を行い, Fairbanks ら ${ }^{18)}$ 方法 にて PAS 染色し, Shimadsu CS-930 にてスキ ヤンした。

\section{4. 交差免疫電気泳動}

交差免疫電気泳動 (CIE) による解析は Hagen ら ${ }^{199}$ の方法に準じて行った. 二次元の 抗体はヒト全血小板で免疫して得られた家兔抗 血清を用いた。泳動後の沈降線は Fairbanks $ら^{18)}$ の方法で Coomassie brilliant blue 染色を 行い観察した。さらに，5 mM EDTAにて処理 した血小板についても同様の解析を行った。

\section{Flow cytometry}

Nomura ら ${ }^{14)}$ の方法により, Flow cytometry を用いて，当教室で作製したヒト

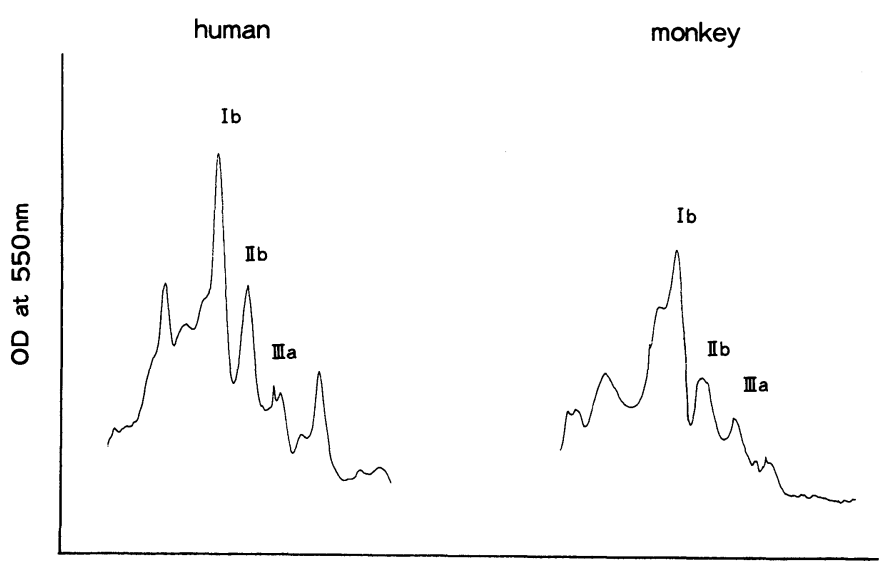

Relative mobility
Fig. 1 Dnsitometric profile of human and monkey platelet glycoproteins after SDS-polyacrylamide gel electrophoresis and PAS staining. 

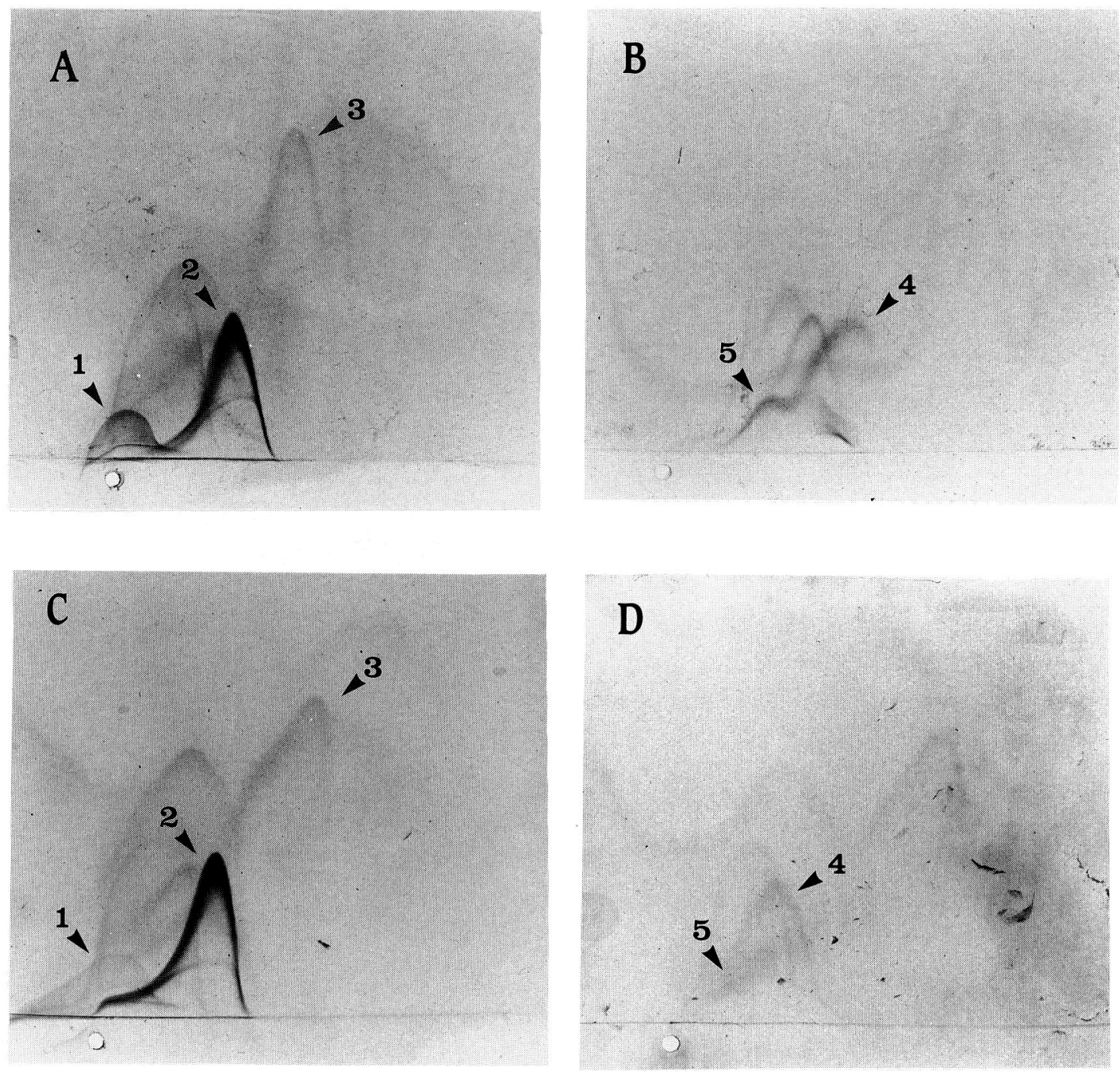

Fig. 2 Crossed immunoelectrophoresis of human and monkey platelet membrans. (A) human platelet without EDTA. (B) human platelet incubated with $5 \mathrm{mM}$ EDTA for 30 min at $37^{\circ} \mathrm{C}$. (C) monkey platelet without EDTA. (D) monkey platelet incubated with $5 \mathrm{mM}$ EDTA for $30 \mathrm{~min}$ at $37^{\circ} \mathrm{C}$. 1 : fibrinogen, $2: \mathrm{GP}$ IIb/IIIa complex, $3: \mathrm{GP} \mathrm{Ib}$, 4 : GP IIb, 5 : GP IIIa.

血小板に対する 9 種のモノクローナル抗体のサ ル血小板に対する結合性を検討した。

\section{6. 血小板凝集能}

$\mathrm{ADP}$, コラーゲン, エピネフリンおよびリス トセチン凝集は PRP を用いて血小板凝集計 (NKK Hematracer 1) で測定した. トロンビ ン凝集は, PRP $1 \mu \mathrm{M} \mathrm{PGE}$ を含む HepesTyrode buffer で 2 回洗浄し, Hepes-Tyrode buffer に再浮遊させ $30 \times 10^{4} / \mu l$ に調整し, 同 じく血小板凝集計で測定した。さらに，Flow cytometry にてサル血小板と結合性を示した 抗ヒト血小板抗体の, サル血小板凝集に及ぼす 影響を検討した。

\section{II. 結 果}

\section{SDS-PAGE}

主要な GPである Ib・IIb・IIIa はヒ卜お よびサル血小板に扔いて, ほぼ同様の PAS 染 色パターンを示した（図1)。 
anti GP $\mathbb{I} b / \mathbb{I I}$ a complex antibodies
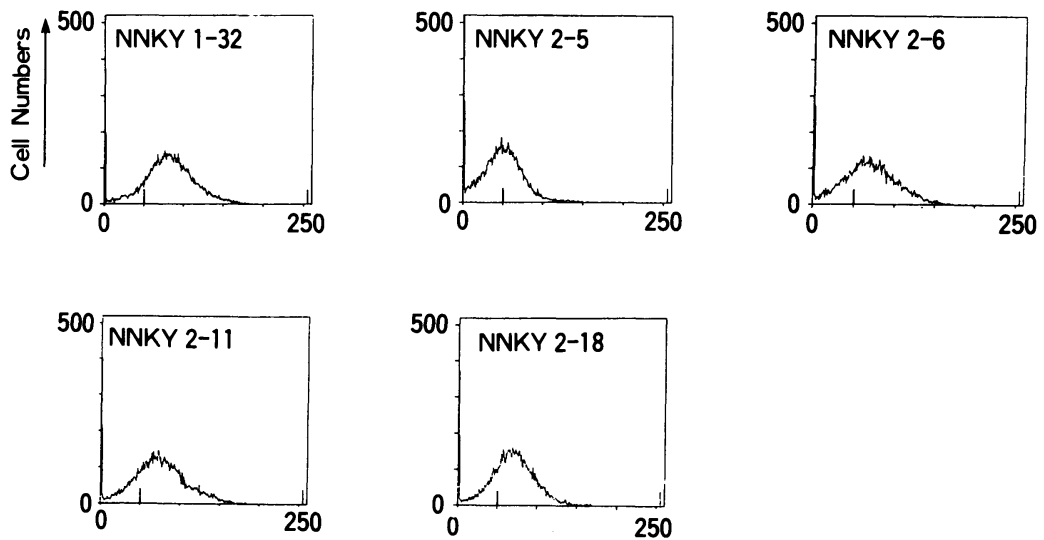

anti GP Ib antibodies
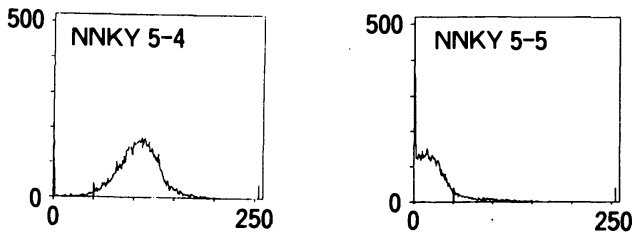

CD9 antibodies
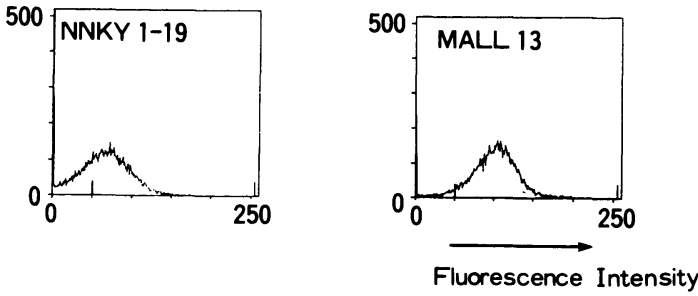

Fig. 3 Fluorescence histogram of monoclonal anti human platelet antibodies for monkey platelets

\section{CIE}

ヒトおよびサル血小板の CIE 像は，ほぼ同 様の沈降線を示し(図 $2 \mathbf{A}, \mathbf{C}$ ), また $5 \mathrm{mM}$ EDTA 添加により, 双方の GP IIb/IIIa 複合 体は解離した（図 2B, D).

\section{Flow cytometry}

サル血小板は，5種の抗ヒト GP IIb/IIIa 複 合体抗体すべてと良好な結合性を示した。ヒト GP Ib に対するモノクローナル抗体のうち NNKY 5-4 と結合したが，NNKY 5-5 とは 結合しなかった。 2 種の CD 9 抗体に対しては 良好な結合性を示した（図 3).

\section{4. 血小板凝集能}

サル血小板は低濃度の ADP によりヒト血小
板と同様の一次凝集を示した. 8 頭中 3 頭のサ ル血小板で $4 \mu \mathrm{M}$ ADP により一次凝集のみが 観察され，二次凝集を惹起させるためには 10 $\mu \mathrm{M}$ の ADP を要した。コラーゲンおよびトロ ンビンにより，ヒト血小板と同様の凝集曲線が 観察された。エピネフリン凝集はいずれのサル 血小板においても認めなかった。終濃度 1.5 $\mathrm{mg} / \mathrm{m} l$ のリストセチンでは凝集は惹起されず, $2.4 \mathrm{mg} / \mathrm{ml}$ のリストセチンによりヒト血小板と 同様の凝集曲線が観察された (図 4)。この時, フィブリノーゲンの沈降はみられなかった。

5. 抗ヒト血小板抗体のサル血小板凝集に及 ぼす影響（表 1)

抗ヒト GP IIb/IIIa 複合体抗体 NNKY 1-32 


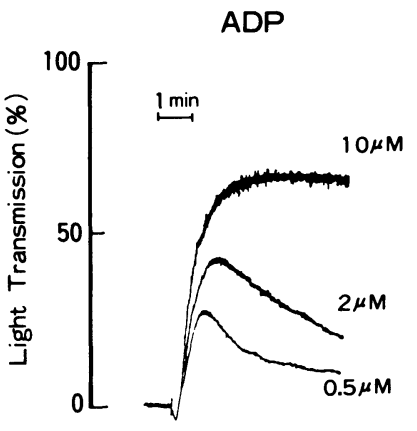

Thrombin

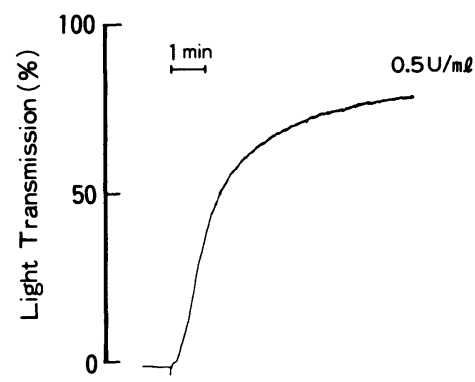

Collagen

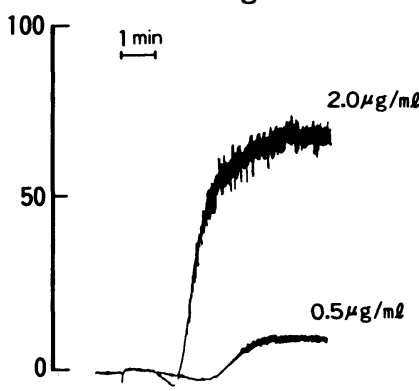

Ristocetin

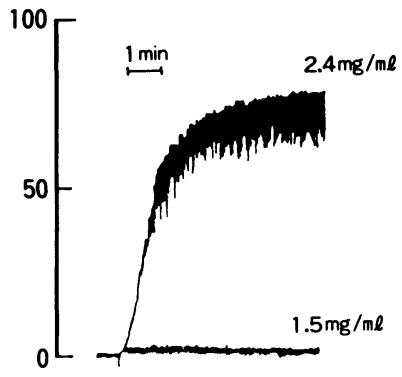

Epinephrine

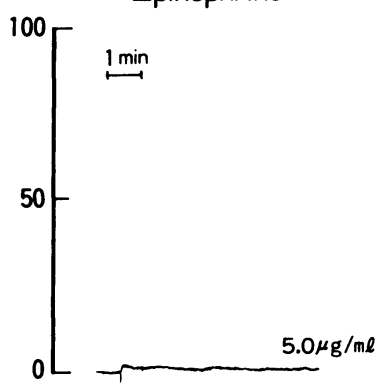

Fig. 4 Monkey platelet aggregation curves

Table 1 Effects of monoclonal anti human platelet antibodies on monkey platelet aggregation

\begin{tabular}{|c|c|c|c|c|c|c|c|}
\hline \multirow{2}{*}{$\begin{array}{l}\text { Monoclonal } \\
\text { antibody }\end{array}$} & \multirow{2}{*}{ Epitopeba } & \multirow{2}{*}{$\begin{array}{l}\text { Induction of } \\
\text { platelet } \\
\text { aggregation }\end{array}$} & \multicolumn{5}{|c|}{ Inhibition of platelet aggregation } \\
\hline & & & $\mathrm{ADP}$ & Collagen & Thrombin & Ristocetin & MALL13 \\
\hline NNKY 1-32 & GP II a/IIIb complex & - & H & $H$ & + & + & H \\
\hline NNKY 2-5 & GP IIb/IIIa complex & - & H & H & + & + & H \\
\hline NNKY 2-6 & GP IIb/IIIa complex & - & + & + & + & + & + \\
\hline NNKY 2-11 & GP IIb/IIIa complex & - & + & + & + & - & + \\
\hline NNKY 2-18 & GP IIb/IIIa complex & - & + & + & + & - & + \\
\hline NNKY 5-4 & GP I b & - & - & - & - & - & - \\
\hline NNKY 1-19 & CD9 antigen & $-\sim \uparrow^{*}$ & - & - & - & - & ～ \\
\hline MALL 13 & CD9 antigen & $\uparrow$ & - & - & - & - & l \\
\hline
\end{tabular}

$\uparrow$ : Platelet aggregation, $\#$ : complete inhibition, + : partial inhibition, - : no effect,

* : NNKY 1-19 induced four of eight monkeys platelet aggregation.

および 2-5 は, サル血小板の ADP およびコラ ーゲン凝集を完全に，トロンビンおよびリスト セチン凝集を部分的に抑制した（図 5)。抗七 卜 GP IIb/IIIa 複合体抗体 NNKY 2-6, 2-11 および 2-18は，サル血小板の $\mathrm{ADP}$ およびコ ラーゲン凝集に対して部分的抑制を示した。

抗ヒト GP Ib 抗体 NNKY 5-4 は, サル血 小板のトロンビンおよびリストセチン凝集に対

して影響を与えなかった。

CD 9 抗体 NNKY 1-19 は8 頭中 4 頭のサ ル血小板を凝集させた. CD 9 抗体 MALL 13
はすべてのサル血小板に対して凝集惹起作用を 示した。また CD 9 抗体によるサル血小板凝集 は, NNKY 1-32 および 2-5により完全に, NNKY 2-6，2-11 および 2-18により部分的に 抑制された（図 6).

NNKY 1 - 32 は F $(a b)_{2}$ 分画や Fab 分画 でも IaG 分画と同様に, サル血小板の $\mathrm{ADP}$, コラーゲンおよび CD 9 抗体による凝集を完全 に,トロンビンおよびリストセチン凝集を部分 的に抑制した。 


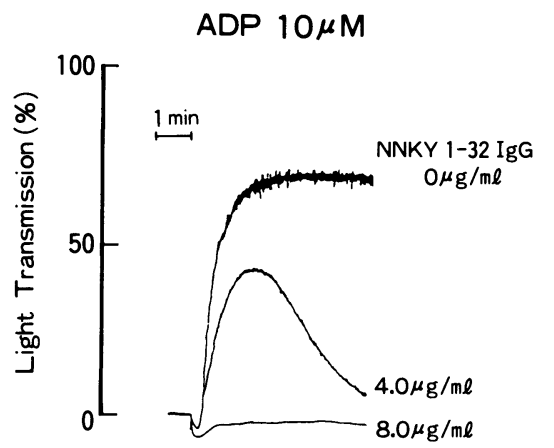

Thrombin $0.5 \mathrm{U} / \mathrm{m} \ell$

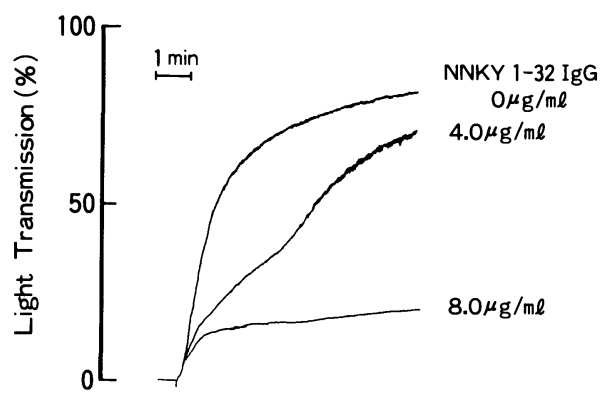

\section{Collagen $2.0 \mu \mathrm{g} / \mathrm{m} \ell$}

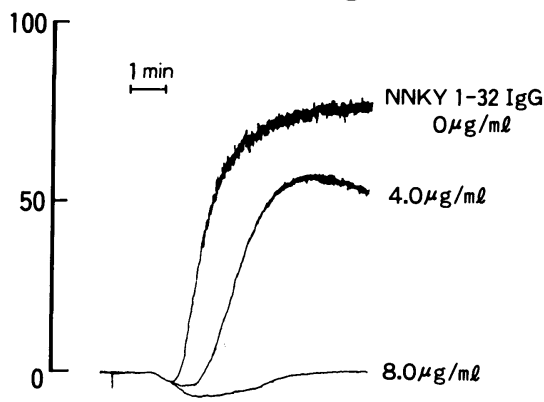

Ristocetin $2.4 \mathrm{mg} / \mathrm{m} \ell$

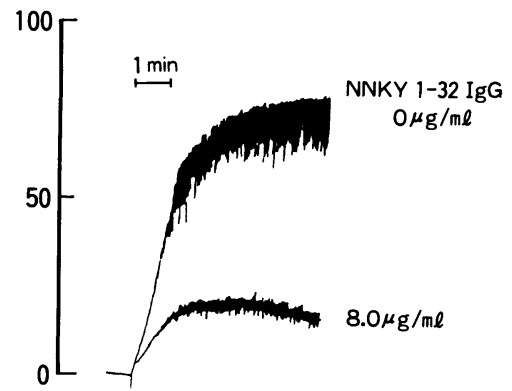

Fig. 5 Effects of NNKY 1-32 on monkey platelet aggregation

\section{III. 考案}

サルは哺乳類の中でも特にヒトに近い種であ り実験動物として貴重な存在である。血小板研 究の分野でサルを用いる場合，ヒト血小板との 類似性や相違点を明らかにすることは重要であ ろう。そこで今回，サル血小板の抗原性や凝集 能をヒト血小板と比較検討した。

SDS-PAGE PCIE による分析では，ヒト血 小板において主要な役割をはたす GPIb・IIb・ IIIa は，サル血小板においてもほほ同様の検査 成績を示した。また，EDTA 処理による GP $\mathrm{IIb} / \mathrm{IIIa}$ 複合体の解離は, ヒト血小板と同様に サル血小板においても観察された。

今回，抗ヒト GP IIb/IIIa 複合体抗体として 用いた 5 種類のモノクローナル抗体のうち, NNKY1-32，2-5および2-6は，ヒト血小板の $\mathrm{ADP}$, コラーゲンおよびエピネフリン凝集を完

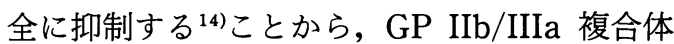
上のフィブリノーゲン結合部位もしくはそのご
く近傍を認識していると考えられる。一方， NNKY2-11 および 2-18 は，ヒト血小板の $\mathrm{ADP}$, コラーゲンおよびエピネフリン凝集に対 し部分抑制を示すことから，GP IIb/IIIa 複合 体上のフィブリノーゲン結合部位からわずかに 離れた位置を認識していると考えられる。これ らの抗体すべてが，サル血小板と良好な結合性 を示し，さらにサル血小板凝集に対してもヒト 血小板凝集に対してとほほ同椂の抑制作用を示 したことから，血小板凝集において重要な役割 をはたす GP IIb/IIIa 複合体上のフィブリノー ゲン結合部位およびその近傍には, 構造的にも 機能的にもヒトとサルの間に多くの共通点があ ることが推測された。

2 種類のヒト GP Ib に対するモノクローナル 抗体のうち，サル血小板と結合した NNKY5-4 は，ヒト血小板のトロンビン凝集にもリストセ チン凝集にも影響を与えないが14), サル血小板 と結合しなかった NNKY5-5 はヒト血小板の リストセチン凝集を完全に抑制する ${ }^{14)}$.また， 


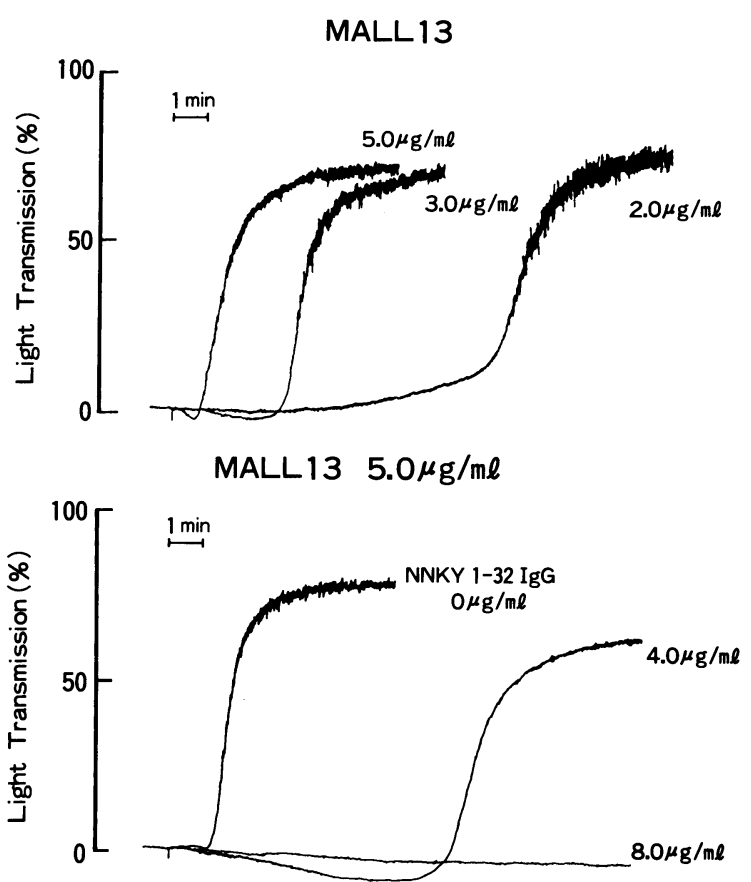

Fig. 6 MALL 13 induced monkey platelet aggregation and its inhibition by NNKY 1 $-32$

サル血小板は $2.4 \mathrm{mg} / \mathrm{m} l$ と高濃度のリストセ チンによりはじめて凝集する。このことから， サル von Willebrand 因子（vWF）に関しては 検討していないが，ヒト血小板とサル血小板の vWF 結合部位には，構造的あるいは機能的な 相違があることが推測された。なお，高濃度の リストセチンをサル PRP に加えた際に観察さ れた凝集は，ヒト血小板のリストセチン凝集と 同様に，肉眼的に大きな凝集塊がみられフィブ リノーゲンの沈降を認めなかったこと，およ び，抗 GP IIb/IIIa 複合体抗体により部分的抑 制を受けることより，非特異的な反応ではなく vWF と GP Ib の結合により惹起された agglutination であると推測される.

今回用いた CD9 抗体のうち, NNKY1-19 は ヒト血小板を免疫原としており，ヒト血小板に 対しては凝集惹起作用を有している ${ }^{15}$ が，サル 血小板に対する凝集惹起作用は半数のサルにつ いてのみ認められた。一方, MALL13 はヒト ALL 細胞を免疫原としており，ヒト血小板に 対しては破壊的に作用する特異な抗体である ${ }^{16)}$ が，サル血小板に対しては凝集惹起作用を示し
た.この 2 種類の抗体が，ヒトあるいはサル血 小板に対して異なった作用を示す機序に関して は今後検討していかなければならないが， MALL13 の方がより強く血小板活性化に働く のではないかと推測される。いずれにしても， サル血小板もヒト血小板と同様に，ある種の CD9 抗体により活性化されることが示された。 今回の成績から，サル血小板は構造的にも機 能的にもヒト血小板と多くの共通点を持つこと が確認され，またヒト血小板凝集に影響を及ぼ すモノクローナル抗体がサル血小板に対しても 同様の効果をきたしうることが明らかになっ た.このことから, 血小板研究の分野におい て, 特に in vivo でモノクローナル抗体が血小 板に及ぼす影響を検討する際にサルは実験動物 として有用であると考えられた。

本論文の要旨は, 第 12 回日本血栓止血学会 (平成元 年 12 月 大阪）において発表した。

\section{文献}

1) Owen C.A., Bowie E.J.W., Zollman P.E., Fass D. N. and Gordon H. : Carrier of porcine von Willebrand's disease. Amer. J. Vet. Res., 35 : 245 248, 1971.

2) Daniels T.M., Fass D.N., White J.G. and Bowie J. W.: Platelet storage pool deficiency in pins. Blood, 67 : 1043 1047, 1986.

3) Fukuoka, Y. and Hugli, T.E. : Demonstartion of a specific $\mathrm{C} 3 \mathrm{a}$ receptor on guinea pig platelets. J. Immunol., 140 : 3496 3501, 1988.

4) Takami H., Nichols $W$ L., Kaese S.E., Miller R. S., Katzmann J.A. and Bowie E.J.W.: Monoclonal antibodies agianst porcine platelet membrane glycoproteins Ib and IIb/IIIa. Blood, 72 : 1740 1747, 1988.

5) Bochner F., Siebert D.M., Rodgers S.E., Mclntosh G.H., James M.J. and Lloyd J.V.: Measurement of aspirin concentration in portal and systemic blood in pigs: effect on platelet aggregation, thromboxane and prostacyclin production. Thromb. Haemost., 61 : 211 216, 1989.

6) Coller B.S. and Scudder L.E. : Inhibition of dog platelet function by in vivo infusion of $\mathrm{F}\left(\mathrm{ab}^{\prime}\right)_{2}$ fragments of a monoclonal antibody to the 
platelet glycoprotein IIb/IIIa receptor. Blood, 66 : 1456 1459, 1985.

7) Coller B.S., Folts J.D., Scudder L.E. and Smith S. R. : Antithrombotic effect of a monoclonal antibody to the platelet glycoprotein IIb/IIIa receptor in an experimental aminal model. Blood, 68 : 783 786, 1986.

8）曽根尚明, 山口和之, 鈴木正彦, 柳父睦政, 曽我哲司, 野村昌作, 永田博一, 粉川皓年, 安永幸二郎: イヌ血 小板との共通抗原を認識する抗ヒト血小板モノク ローナル抗体について. 日栓会誌, $1: 482 \sim 488$, 1990.

9) Silver M.J., Hoch W., Kocsis J.J., Ingerman C.M. and Smith J.B.: Arachidonic acid causes sudden death in rabbits. Science, $183: 1085 \sim 1087,1974$.

10) Harfenist E.J., Packham M.A. and Mustard J.F.: Expression of fibrinogen on the surface of ADP. stimulated platelets: Comparison of human and rabbit platelets. Thromb. Haemost., 59 : 319 $\sim 322,1988$.

11）鈴木正彦, 永田博一, 柳父睦政, 曾我哲司, 大賀成敏, 曽根尚明, 野村昌作, 粉川皓年, 安永幸二郎 : CD9 抗 体の家兔への全身投与の影響. 日血会誌, $53: 1222$ 〜228, 1990.

12）野村昌作, 永田博一, 北田親穂, 曾根尚明, 織田一弘, 粉川皓年, 安永幸二郎, 中島鉄夫, 遠藤啓吾 : Flow Cytometry を用いた血小板無力症及び BernardSoulier 症候群の解析. 臨床血液, $28: 377 \sim 385$, 1987.

13) Nomura S., Nagata H., Oda K., Kokawa T. and Yasunaga K. : Effects of EDTA on the membrane glycoprotein IIb-IIIa complex -analysis using flow cytometry - Thromb. Res., $47: 47 \sim 58$, 1987.

14) Nomura S., Nagata H., Sone N., Oda K., Kokawa T. and Yasunaga K. : Analysis of platelet antigen for antiplatelet antibodies in idiopathic thrombocytopenic purpura using flow cytometry. Acta Haematol. Jpn., 51 : 118 129, 1988.

15）永田博一, 野村昌作, 曾根尚明, 北田親穂, 平居啓治, 橋爪 誠, 織田一弘, 粉川皓年, 安永幸二郎: CD9 （p24）抗原の機能的役割について. 血液と脈管. 18: 336 339, 1987.

16) Nagata H., Nomura S., Sone N., Suzuki M., Kokawa T. and Yasunaga K.: A new monoclonal antibody, MALL13, which induces platelet activation and cytolysis. Acta Haematol. Jpn., $53:$ :156 1171, 1990.

17) Laemmmli U.K. : Cleavage of structural proteins during the assembly of the head bacteriophage T4. Nature, $227: 680 \sim 685,1970$.

18) Fairbanks G., Steck T.L., Wallach D.F.H.: Electrophoretic analysis of the major polypeptides of the human erythrocyte membrane. Depotition of the major proteins in isolated erythrocyte membrane. Proteolytic dissection. Biochemistry, 10 : 2606 2624, 1971.

19) Hagen I., Bjerrum O.J., Solum N.O. : Characterization of human platelet proteins solubilized with Triton X-100 and examined by crossed immunoelectrophoresis. Eur. J. Biochem., 99 : 9 22, 1979. 